\title{
Kualitas Perairan di tinjau dari Distribusi Fitoplankton serta Indeks Saprobik di Pantai Marina Semarang Jawa Tengah
}

\author{
Widigdo Bagus Bagaskara*, Raden Ario, Ita Riniatsih \\ Departemen IImu Kelautan, Fakultas Perikanan dan Ilmu Kelautan, Universitas Diponegoro \\ J. Prof. H. Soedarto S.H, Tembalang, Semarang, Jawa Tengah 50275 Indonesia \\ *Corresponding author, e-mail : bagvsbagaskara@gmail.com
}

\begin{abstract}
ABSTRAK: Pantai Marina di Semarang, Jawa Tengah merupakan salah satu objek wisata di kota Semarang. Di perairan Pantai Marina Semarang terdapat muara yang menghubungkan sungai Banjir Kanal Barat dengan sungai Banjir Kanal Timur sehingga pada muara ini bertemunya antara perairan laut dan tawar yang mana pada sepanjang bantaran sungai tersebut terdapat bebagai kegiatan industri serta merupakan tempat penduduk setempat untuk bermukin dan beraktivitas. Sehingga, pada sungai tersebut akan membawa material material orgnaik maupun anorganik yang bermuara di Pantai Marina. Sehingga perairan Pantai Marina di Semarang, Jawa Tengah ini secara tidak langsung terpengaruh oleh aktifitas industri maupun penduduk setempat. Selain itu, adanya pembuangan limbah rumah tangga yang masuk ke dalam badan sungai yang juga berdampak bagi perubahan kualitas perairan serta kehidupan ekosistem di sepanjang aliran sungai tersebut. Fitoplankton merupakan organisme perairan yang keberadaannya dapat dijadikan sebagai indikator kualitas perairan. Metode yang digunakan adalah metode deskriptif. Pengambilan sampel dilakukan sebanyak tiga kali dengan interval dua minggu sekali di tiga stasiun, masing masing stasiun dilakukan pengambilan sampel sebanyak tiga kali. Stasiun 1 merupakan perairan pantai, stasiun 2 merupakan muara dan stasiun 3 merupakan perairan air laut. Hasil penelitian menunjukkan bahwa terdapat 19 genus fitoplankton dari 3 kelas, yaitu 14 genus dari kelas Bacillariophyceae, 3 genus dari kelas Dinophyceae dan 2 genus dari kelas Cyanophyceae dengan kelimpahan rata-rata fitoplankton sebesar $20394,24 \%$, indeks keanekaragaman sedang $\left(H^{\prime}=2,36-2,55\right)$. Indeks keseragaman tinggi $(E=0,81-0,89)$, indeks dominansi termasuk dalam kategori tidak ada jenis yang mendominasi dengan nilai indeks yang berkisar antara 0,11-0,17 serta indeks saprobik termasuk dalam kategori $\alpha-$ Mesosaprobik dengan nilai berkisar antara $-0,89--1,19$
\end{abstract}

Kata kunci: Fitoplankton; kualitas perairan; indeks saprobik

\section{Relationship between Phytoplankton Distribution and Water Quality at Marina Beach Semarang Central Java}

ABSTRACT: Marina Beach in Semarang, Central Java is a place that meets the sea and freshwater, because there is a estuary of the East Canal Flood and the West Canal flood which, along the river is a variety of industrial activities and is a place for people to settle and stay. Until the waters of Marina Beach in Semarang, Central Java is indirectly affected by industrial activities and local residents. In addition, the disposal of household waste that entering the body of the river that also affects the changes in the quality of the water and ecosystem life along the river flow. Phytoplankton is an aquatic organism in which its existence can serve as an indicator of water quality. The study was conducted in October to December 2019. The method used is a descriptive method. The sampling was conducted three times with a two-week interval at three stations, each of which was performed three times for sampling. Station 1 is the coastal waters, station 2 is the estuary and the station 3 is the sea water waters. The results showed that there are 19 genus phytoplankton of 3 classes, namely 14 genera of class Bacillariophyceae, 3 genera of the Dinophyceae class and 2 genera of Cyanophyceae class with an average abundance of phytoplankton by $17945,36 \mathrm{mg} / \mathrm{l}$ $20394.24 \mathrm{mg} / \mathrm{l}$, index Medium diversity $\left(H^{\prime}=2.36-2.55\right)$. High uniformity index $(E=0.81-$ 0.89), the dominance index belongs to the category of no dominant type with an index value 
ranging from 0.11 - 0.17 as well as a saprobic index belonging to the category $\alpha$ Mesosaprobik with values ranging from $(-0.89)-(-1.19)$

Keywords: Phytoplankton; Water Quality; Saprobic Indeks

\section{PENDAHULUAN}

Kota Semarang adalah salah satu kota pesisir di Indonesia dan terletak di pesisir utara Jawa dengan luas $37.376 \mathrm{Ha}$, Kota Semarang menjadi pusat perdagangan dan industri di Provinsi Jawa Tengah. Wilayah pesisir adalah pusat kegiatan manusia yaitu termasuk pusat perdagangan, industri, akuakultur, perikanan tangkap, pariwisata dan rumah (Nuriasih et al., 2018). Pantai Marina di Semarang, Jawa Tengah merupakan tempat bertemunya perairan laut dan tawar karena terdapat muara sungai Banjir Kanal Timur dan Banjir Kanal Barat yang sepanjang bantaran sungai tersebut terdapat berbagai kegiatan industri serta merupakan tempat penduduk setempat untuk bermukim dan beraktifitas. Kegiatan - kegiatan tersebut pada umumnya menghasilkan limbah maupun sampah yang dibuang langsung ke perairan sungai sehingga secara tidak langsung pencemaran tersebut dapat menyebabkan penurunan kadar kualitas perairan pada pantai tempat sungai tersebut bermuara (Suhartono, 2010).

Plankton merupakan organisme yang hidup melayang di dalam air. Organisme ini mempunyai kemampuan gerak yang sangat terbatas, sehingga sebaran organisme ini dipengaruhi oleh kondisi arus perairan. Plankton dapat di bagi menjadi dua yaitu fitoplankton dan zooplankton (Yulianto et al., 2017). Plankton mempunyai peran yang sangat besar dalam ekosistem perairan, karena sebagai sumber makanan bagi hewan perairan lainnya. Distribusi Fitoplankton dipengaruhi oleh ketersediaan cahaya dalam perairan atau tersebar dalam zona eufotik. Kemampuan membentuk zat organik dari zat anorganik dalam perairan menjadikan fitoplankton dikenal sebagai produsen primer (Simanjuntak, 2009). Dalam rantai makanan (tingkat tropik), fitoplankton menduduki posisi paling bawah sebagi sumber makanan utama untuk hewan-hewan perairan. Dapat dikatakan bahwa perairan yang produktivitas primer fitoplanktonnya tinggi akan mempunyai potensi sumberdaya hayati yang besar.

Budidaya laut sangat dipengaruhi oleh kondisi lingkungan perairan yang meliputi faktor fisik, kimia, dan biologi (kesuburan perairan). Kesuburan perairan dapat diindikasikan dengan kelimpahan fitoplankton yang tersedia. Perubahan terhadap kualitas perairan dapat ditinjau dari kelimpahan dan komposisi Fitoplankton. Keberadaan fitoplankton di suatu perairan dapat memberikan informasi mengenai kondisi perairan melalui Indeks Saprobik (Sari et al., 2014). Penelitian ini bertujuan untuk mengetahui jenis, kelimpahan, indeks ekologi serta indeks saprobik untuk mengetahui kualitas perairan di Pantai Marina Semarang Jawa Tengah

\section{MATERI DAN METODE}

Materi yang digunakan dalam penelitian ini adalah fitoplankton yang terdapat pada sampel air yang diambil dari lokasi penelitian di Pantai Marina Semarang. Pengambilan sampel diambil secara acak berdasarkan stasiun - stasiun yang telah ditentukan yaitu pada perairan Pantai Marina, Muara Sungai Banjir Kanal Barat dan Perairan Tengah Laut menggunakan Plankton net. Bersamaan dengan pengambilan sampel fitoplankton dilakukan pengukuran parameter lingkungan meliputi suhu, salinitas, $\mathrm{pH}$, oksigen terlarut, nitrat, fosfat, kecerahan dan kecepatan arus.

Metode yang digunakan dalam penelitian ini adalah metode deskriptif. Menurut (Nawawi, 2012) bahwa penelitian deskriptif yaitu suatu metode penelitian yang ditujukan untuk menggambarkan fenomena-fenomena yang ada, yang berlangsung pada saat ini atau saat yang lampau. Periode I dilakukan tanggal 31 Oktober 2019, Periode II tanggal 14 November 2019 dan Periode III tanggal 28 November 2019. Data dideskripsikan kedalam bentuk tabel dan grafik, sementara analisis data meliputi Kelimpahan, Indeks Keanekaragaman, Indeks Keseragaman, Indeks Dominasi serta Indeks Saprobik.

Menurut Nurcahyani et al., (2016), data yang telah diperolehkan kemudian di olah untuk mengetahui kelimpahan, dan indeks fitoplankton (keanekaragaman, keseragaman, dominasi) serta 
Indeks Saprobik. Kelimpahan organisme dalam suatu perairan dapat dinyatakan sebagai jumlah individu per liter. Basmi (2000), menyatakan bahwa perairan digolongkan berdasarkan kelimpahan individu, yaitu : Perairan Oligotrofik, Perairan Mesotrofik dan Perairan Eutrofik Penentuan kelimpahan plankton (fitoplankton) menggunakan rumus dari APHA, (1989).

Indeks keanekaragaman digunakan untuk mengetahui keanekaragaman jenis fitoplankton di perairan tersebut. Persamaan yang digunakan untuk menghitung indeks ini adalah berdasarkan rumus Shannon dan Wiener Odum, (1993). Menurut (Adiwilaga et al., 2012) mengatakan bahwa kriteria indeks keseragaman adalah $\mathrm{E}<0,4=$ Keseragaman rendah; $0,4<\mathrm{E}<0,6=$ Keseragaman sedang; $E>0,6=$ Keseragaman tinggi

Menurut (Odum, 1993) menyatakan bahwa nilai dominansi berkisar antara 0-1. Nilai indeks dominansi yang mendekati 0 berarti hampir tidak ada dominansi oleh suatu spesies dalam komunitas. Nilai indeks dominansi yang mendekati 1 berarti ada dominansi oleh suatu spesies dalam komunitas tersebut. Kriteria indeks dominasi dibagi menjadi 2 yaitu :0<D<0,5= Tidak ada jenis yang mendominasi; $0,5<\mathrm{D}<1=$ Terdapat jenis yang mendominasi

Sistem Saprobitas digunakan untuk melihat kelompok organisme yang dominan dan banyak digunakan untuk menentukan tingkat pencemaran dengan persamaan Dresscher dan Van Der Mark (1976).

\section{HASIL DAN PEMBAHASAN}

Secara keseluruhan pada Periode I ditemukan 19 genus yang termasuk dalam 3 kelas yaitu Bacillariophyceae (terdapat 14 genus yaitu Rhizosolenia, Pleurosigma, Coscinodiscus, Striatella, Nitzchia, Diatoma, Chaetoceros, Thalassiotrix, Fragillaria, Eucampia, Biddulphia, Thalassionema, Stephanopyxis, Bacteriastrum), Dinophyceae (terdapat 3 genus yaitu Ceratium, Protoperidinium, Prorocentrum) dan Cyanophyceae (terdapat 2 genus yaitu Oscillatoria dan Spirulina). Periode II ditemukan 17 genus yang termasuk dalam 3 kelas yaitu Bacillariophyceae (terdapat 12 genus yaitu Rhizosolenia, Pleurosigma, Coscinodiscus, Striatella, Nitzchia, Diatoma, Thalassiotrix, Eucampia, Biddulphia, Stephanopyxis, Chaetoceros, Flagillaria), Dinophyceae (terdapat 3 genus yaitu Dinophysis, Ceratium, Protoperidinium) dan Cyanophyceae (terdapat 2 genus yaitu Spirulina dan Oscillatoria). Periode III ditemukan 18 genus yang termasuk dalam 3 kelas yaitu Bacillariophyceae (terdapat 13 genus yaitu Rhizosolenia, Pleurosigma, Coscinodiscus, Nitzchia, Diatoma, Chaetoceros, Thalassiotrix, Eucampia, Biddulphia, Bacteriastrum, Stephanopyxis, Asterionella, Stephanodiscus), Dinophyceae (terdapat 3 genus yaitu Ceratium, Protoperidinium, Prorocentrum), Cyanophyceae (terdapat 2 genus yaitu Spirulina dan Oscillatoria) (Gambar 1.)

Ketiga pengulangan menunjukkan hasil yang berbeda, pada Periode I kelimpahan tertinggi terdapat pada stasiun 2 dengan jumlah 22021.79 sel/L, sedangkan kelimpahan terendah terdapat pada stasiun 1 dengan jumlah 19159.23 sel/L. Pada Periode II kelimpahan fitoplankton tertinggi terdapat pada stasiun 2 dengan jumlah 20871.33 sel/L, sedangkan kelimpahan terendah terdapat pada stasiun 1 dengan jumlah 19267.94 sel/L. Pada Periode III kelimpahan fitoplankton tertinggi terdapat pada stasiun 2 dengan jumlah $19566.88 \mathrm{sel} / \mathrm{L}$, sedangkan kelimpahan terendah terdapat pada stasiun 1 dengan jumlah $16631.84 \mathrm{sel} / \mathrm{L}$ (Gambar 2.)

Indeks keanekaragaman ( $\left.\mathrm{H}^{\prime}\right)$ fitoplankton di Perairan Pantai Marina Semarang berkisar antara 0,96-1,11 dan termasuk dalam kategori sedang. Nilai keanekaragaman tertinggi terdapat pada pengulangan II dengan nilai rata - rata 1,06 sedangkan nilai keanekaragaman terendah terdapat pada pengulangan III dengan nilai rata - rata 1,03. Indeks keanekaragaman fitoplankton di Perairan Pantai Marina Semarang secara lengkap tersaji dalam Gambar 3. Indeks Keseragaman (E) fitoplankton di Perairan Pantai Marina Semarang secara keseluruhan berkisar antara 0,81-0,89 dan termasuk dalam kategori tinggi. Nilai keseragaman tertinggi terdapat pada pengulangan II dengan nilai rata - rata 0,88 sedangkan nilai keseragaman terendah terdapat pada pengulangan I dan pengulangan III dengan nilai rata - rata 0,84 . Indeks keseragaman fitoplankton di Perairan Pantai Marina Semarang secara lengkap tersaji dalam Gambar 4. Indeks dominansi fitoplankton di Pantai Marina Semarang berkisar antara 0,10-0,17 dimana nilai tersebut termasuk dalam kategori tidak mendominasi. Nilai dominasi tertinggi terdapat pada pengulangan III dengan nilai rata - rata 0,14 sedangkan nilai dominasi terendah terdapat pada pengulangan 2 dengan nilai rata - rata 0,12. Indeks dominasi fitoplankton di Perairan Pantai Marina Semarang secara lengkap 
tersaji dalam Gambar 5. Hasil identifikasi fitoplankton di Perairan Pantai Marina terdapat beberapa spesies yang termasuk dalam kelompok organisme penyusun indeks saprobik. Fitoplankton yang diidentifikasi dan termasuk dalam kelompok organisme penyusun indeks saprobik yaitu Biddulphia, Spirullina (polisaprobik), Chaetoceros, Nitzschia, Rhizosolenia, ( $\alpha$ - Mesosaprobik) Ceratium, Asterionela ( $\beta$-Mesosaprobik) dan tidak di temukan kelompok oligosaprobik. Hasil perhitungan indeks saprobik tersaji pada Gambar 6.

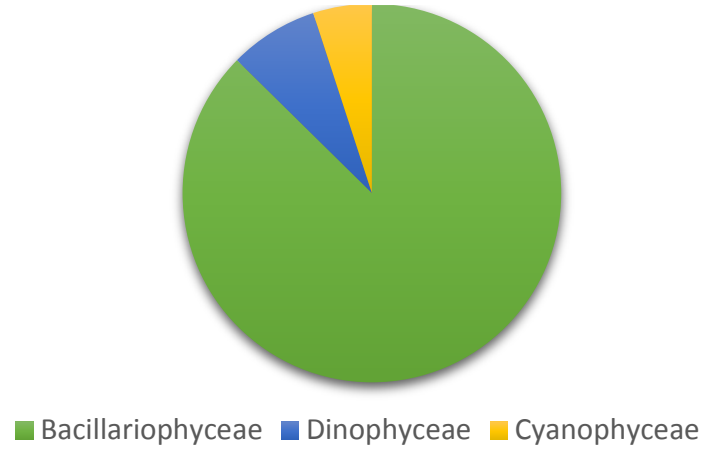

Periode 1

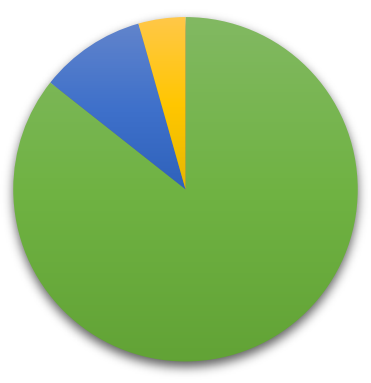

Bacillariophyceae Dinophyceae Cyanophyceae

Peiode 2

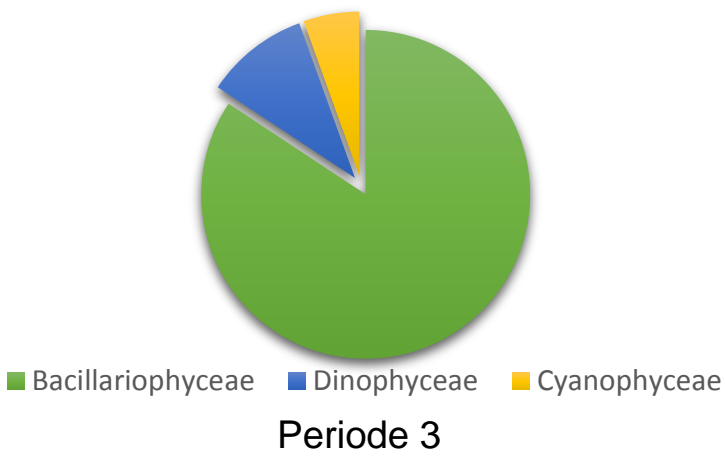

Gambar 1. Diagram Kelimpahan Komposisi Fitoplankton di Pantai Marina Semarang

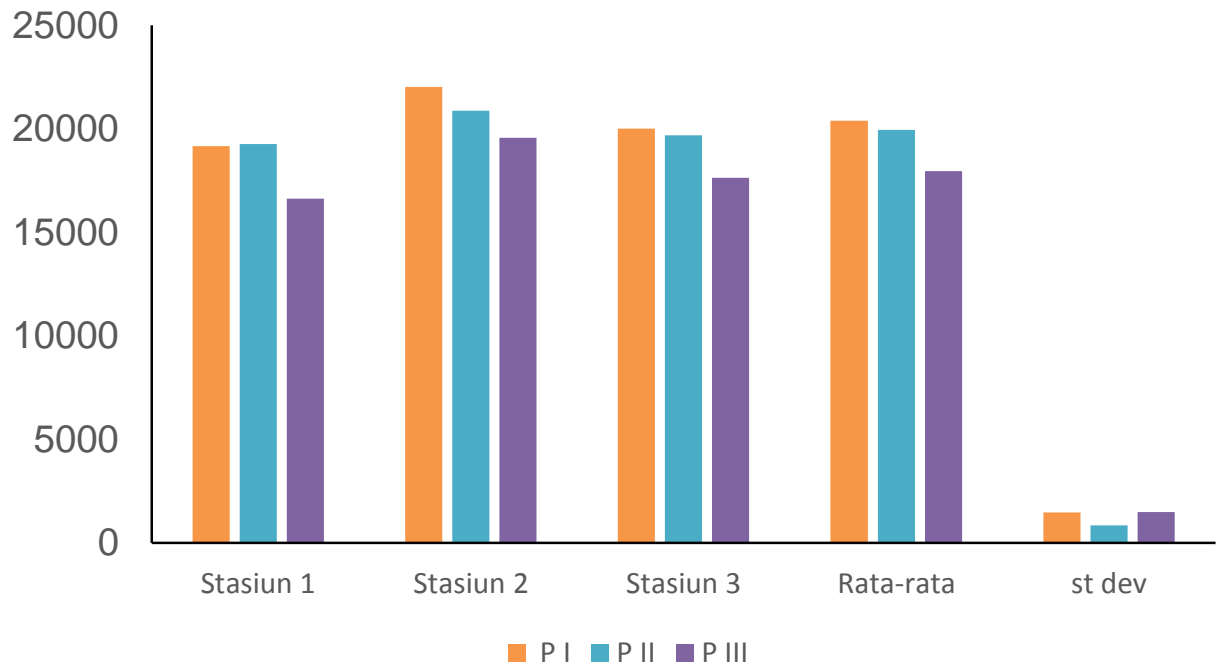

Gambar 2. Grafik Kelimpahan Fitoplankton di Perairan Pantai Marina Semarang 


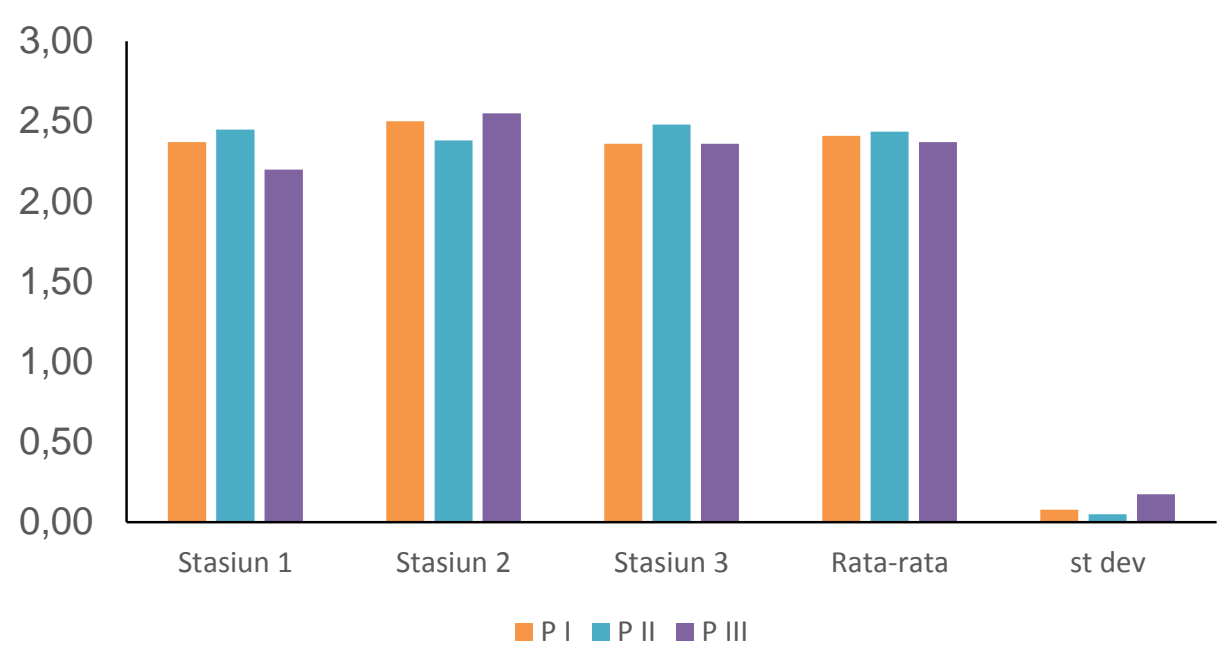

Gambar 3. Grafik Indeks Keanekaragaman Perairan Pantai Marina Semarang

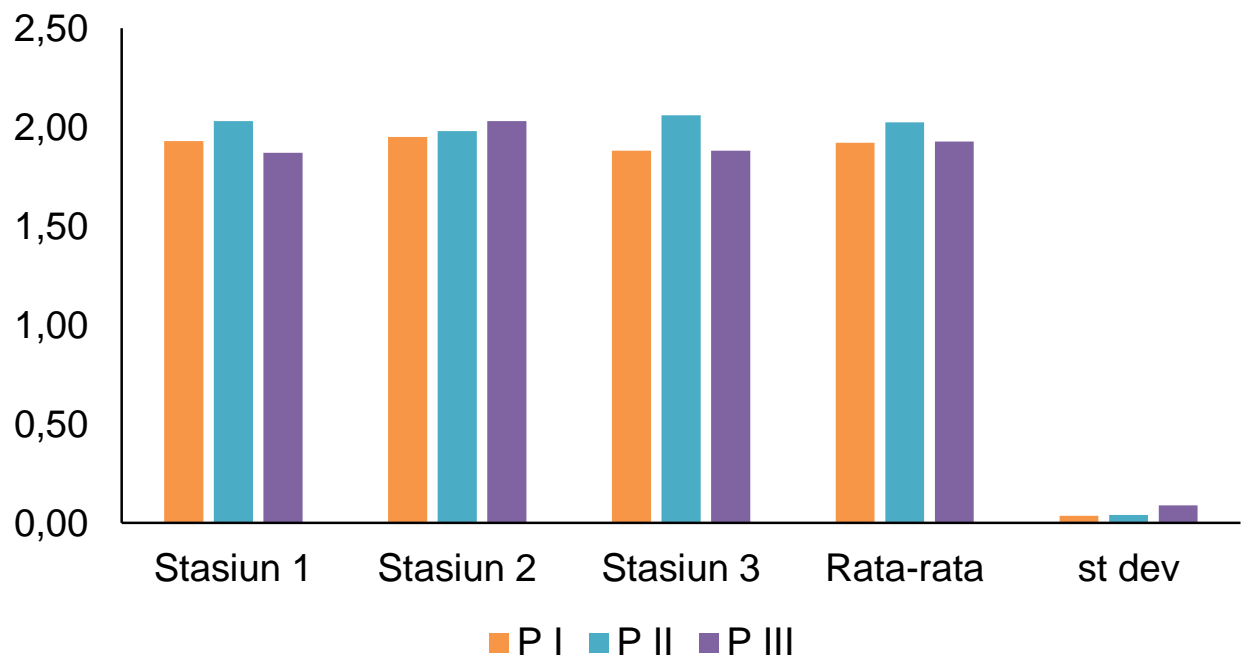

Gambar 4. Grafik Indeks Keseragaman Fitoplankton di Perairan Pantai Marina, Semarang

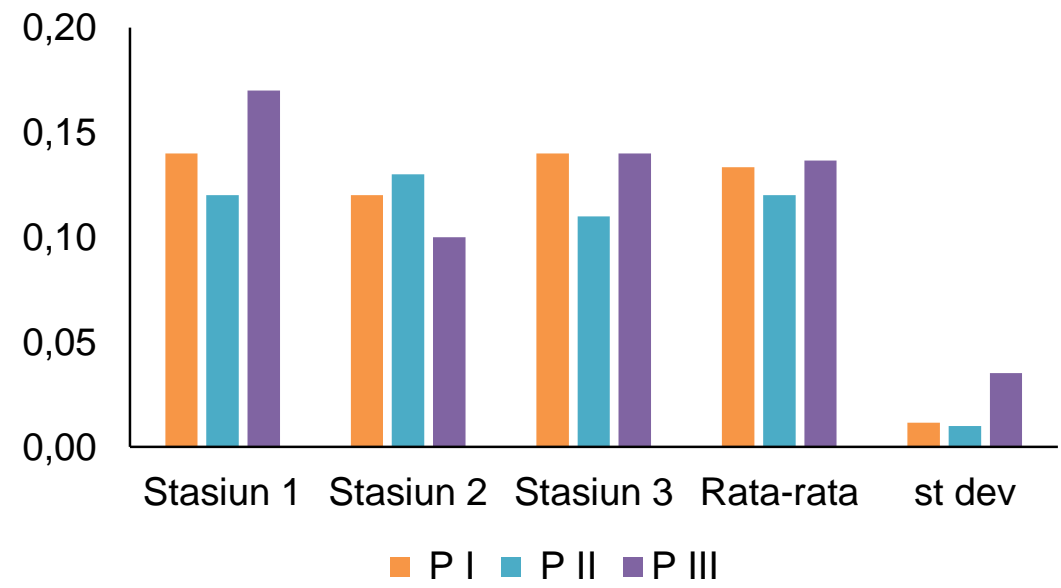

Gambar 5. Grafik Indeks Dominansi Fitoplankton di Perairan Pantai Marina, Semarang

Pengukuran parameter perairan pada Perairan Pantai Marina Semarang meliputi suhu, kecerahan, arus, salinitas, pH, DO, Nitrat serta Fosfat. Pengukuran parameter tersebut 
dilaksanakan pada setiap stasiun untuk menggambarkan kondisi lingkungan perairan daerah penelitian tersebut, lalu pada pengukuran nitrat dan fosfat diujikan di laboratorium BP2 Semarang Tabel 1).

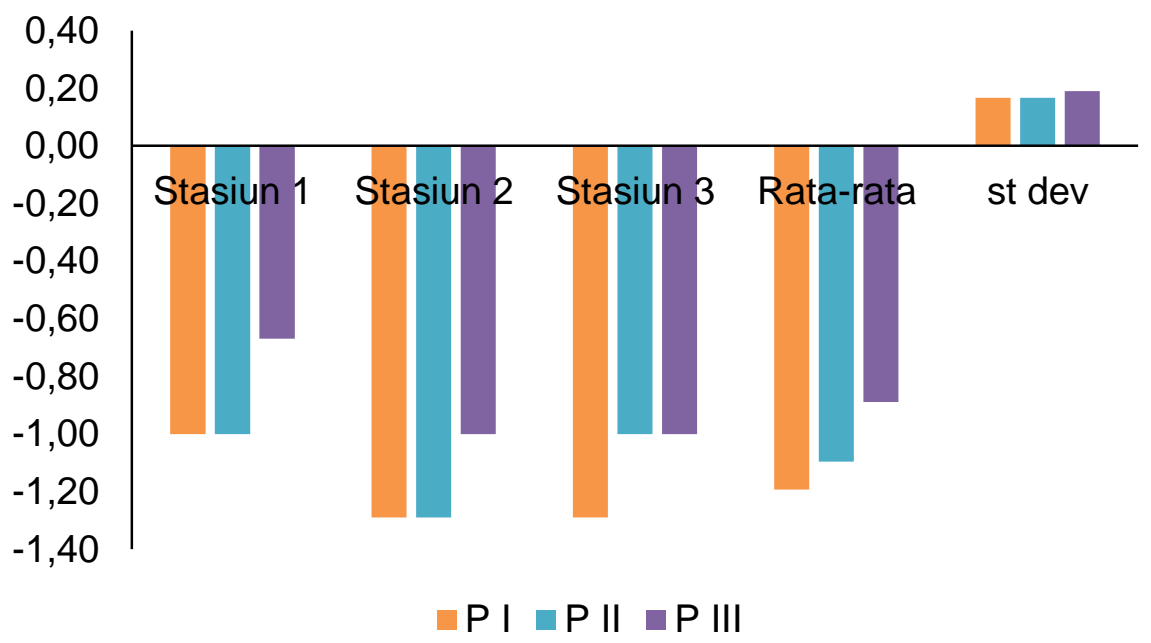

Gambar 6. Nilai Indeks Saprobik di Pantai Marina Semarang

Tabel 1. Pengukuran Parameter Perairan di Perairan Pantai Marina Semarang

\begin{tabular}{|c|c|c|c|c|}
\hline \multirow{2}{*}{ Parameter } & \multirow{2}{*}{ Satuan } & \multicolumn{3}{|c|}{ Stasiun } \\
\hline & & 1 & 2 & 3 \\
\hline \multicolumn{5}{|l|}{ Periode I } \\
\hline Suhu & ${ }^{\circ} \mathrm{C}$ & 31 & 31 & 32 \\
\hline Kecerahan & $\mathrm{cm}$ & 20 & 26 & 88 \\
\hline Arus & $\mathrm{m} / \mathrm{s}$ & 0,2 & 0,2 & 0,4 \\
\hline Salinitas & $\%$ & 29 & 27 & 35 \\
\hline $\mathrm{pH}$ & & 7 & 7 & 8 \\
\hline DO & $\mathrm{mg} / \mathrm{l}$ & 5,83 & 5,70 & 5,98 \\
\hline Nitrat & $\mathrm{mg} / \mathrm{l}$ & 0,5234 & 0,4511 & 0,5277 \\
\hline Fosfat & $\mathrm{mg} / \mathrm{l}$ & 0,0914 & 0,1295 & 0,1284 \\
\hline \multicolumn{5}{|l|}{ Periode II } \\
\hline Suhu & ${ }^{\circ} \mathrm{C}$ & 28 & 32 & 32 \\
\hline Kecerahan & $\mathrm{cm}$ & 16 & 26 & 93 \\
\hline Arus & $\mathrm{m} / \mathrm{s}$ & 0,2 & 0,1 & 0,2 \\
\hline Salinitas & $\%$ & 30 & 28 & 35 \\
\hline $\mathrm{pH}$ & & 7 & 7 & 8 \\
\hline DO & $\mathrm{mg} / \mathrm{l}$ & 5,41 & 5,67 & 5,90 \\
\hline Nitrat & $\mathrm{mg} / \mathrm{l}$ & 0,3777 & 0,7339 & 0,6609 \\
\hline Fosfat & $\mathrm{mg} / \mathrm{l}$ & 0,1305 & 0,3147 & 0,1627 \\
\hline \multicolumn{5}{|l|}{ Periode III } \\
\hline Suhu & ${ }^{\circ} \mathrm{C}$ & 31 & 30 & 31 \\
\hline Kecerahan & $\mathrm{cm}$ & 25 & 27 & 91 \\
\hline Arus & $\mathrm{m} / \mathrm{s}$ & 0,1 & 0,2 & 0,2 \\
\hline Salinitas & $\%$ & 29 & 28 & 33 \\
\hline $\mathrm{pH}$ & & 7 & 7 & 8 \\
\hline DO & $\mathrm{mg} / \mathrm{l}$ & 5,62 & 5,53 & 5,84 \\
\hline Nitrat & $\mathrm{mg} / \mathrm{l}$ & 0,4641 & 0,5316 & 0,5232 \\
\hline Fosfat & $\mathrm{mg} / \mathrm{l}$ & 0,0626 & 0,3667 & $<0,006$ \\
\hline
\end{tabular}


Persentase diagram jenis-jenis fitoplankton yang ditemukan selama penelitian terdapat pada Gambar 1 Fitoplankton dari kelas Bacillariophyceae (Rhizosollenia dan Thallasiothrix) merupakan kelas yang paling banyak ditemukan baik pada pengambilan pada bulan Oktober - November. Chapman et al., (2001) menyatakan bahwa Bacillariophyceae bersifat kosmopolitan, tahan terhadap kondisi ekstrem, mudah beradaptasi, dan mempunyai daya reproduksi yang sangat tinggi. Menurut Effendi (2003) Bacillariophyceae akan tumbuh baik pada kisaran suhu $20-30{ }^{\circ} \mathrm{C}$ begitu pula pendapat Welch (1980) suhu air optimum bagi kelas Bacillariophyceae adalah 20 - 30 ${ }^{\circ} \mathrm{C}$ dan pada kisaran suhu tersebut pembelahan sel dapat berlangsung lebih cepat. Hal ini sesuai dengan Hutabarat dan Evans, (1986) yang mengungkapkan bahwa suhu air optimum rata-rata berkisar antara $24-32^{\circ} \mathrm{C}$ pada kisaran tersebut plankton dapat tumbuh dan berkembang dengan baik. Menurut Nybakken (1992) bahwa salinitas yang baik untuk pertumbuhan plankton di laut adalah 30 - 35 ppt. Hasil dari pengukuran salinitas di Perairan Pantai Marina Semarang Jawa Tengah berada di kisaran ideal salinitas. Hal ini menunjukan bahwa pada perariran Pantai Marina banyak di temukan spesies fitoplankton dari kelas Bacillariophyceae karena memiliki kisaran salinitas yang cocok untuk kehidupan Bacillariophyceae. Komposisi dari kelas Dinophyceae berkisar dari $8 \%-10 \%$. Kelas Cyanophyceae hanya ditemukan 2 genus dan paling sedikit diantara kelas lainnya. Menurut Munthe et al., (2012) Kelas Cyanophyceae sangat jarang ditemukan sehingga mengakibatkan nilai kelimpahan rata-rata kelas tersebut lebih rendah dibandingkan kelas Bacillariophyceae. Nontji (2007) menambahkan bahwa Cyanophyceae biasanya jarang dijumpai, tetapi kadang-kadang akan muncul tiba-tiba dalam ledakan populasi yang amat besar dan tak lama kemudian akan menghilang lagi dengan sangat cepat.

Berdasarkan hasil, kelimpahan rata - rata fitoplankton di Perairan Marina Semarang berkisar antara 17945,36 - 20394,24 sel/L. Kelimpahan fitoplankton tertinggi terdapat pada Pengulangan I yaitu sebanyak 20394,24 sel/L dan terendah terdapat pada Pengulangan III yaitu sebanyak 17945,36 sel/L. Cahaya matahari sendiri sangat diperlukan oleh fitoplankton dan tumbuhan lainnya untuk berfotosintesis. Berdasarkan hasil penelitian dari Yulianto et al., (2014), kelimpahan fitoplankton harian tertinggi terdapat pada pukul 10.00 - 14.00 WIB dimana pada waktu tersebut intensitas cahayanya sesuai untuk fitoplankton melakukan fotosintesis. Dapat disimpulkan bahwa intensitas cahaya matahari dapat mempengaruhi kelimpahan fitoplankton di suatu perairan. Adiwilaga et al., (2012) menyatakan bahwa distribusi cahaya di perairan pada umumnya tidak serasi dengan kebutuhan fitoplankton.

Nilai indeks keanekaragaman jenis fitoplankton di Perairan Pantai Marina selama penelitian dari bulan ke bulan di tampilkan pada Gambar 3. Nilai indeks keanekaragaman jenis fitoplankton pada masing - masing stasiun bervariasi dari bulan ke bulan yaitu dari 0,96 - 1,11. Menurut Siagian (2012) menyatakan bahwa hal ini erat kaitannya dengan kelimpahan fitoplankton yang semakin menurun, Indeks keanekaragaman yang bevariasi dari bulan ke bulan dapat terjadi karena jumlah jenis dan jumlah individu/jenis yang berbeda - beda sehingga di dapatkan nilai indeks keanekaragaman yang berbeda. Hal yang sama di kemukakan Fachrul (2007) yang membuat kriteria kualitas air termasuk tercemar ringan, apabila indeks keanekaragaman antara 2-3. Apabila indeks keanekaragaman yang diperoleh dari penelitian ini di bandingkan dengan pendapat di atas maka Perairan Pantai Marina termasuk pada kriteria tercemar ringan

Menurut Insafitri (2010) yang dimaksud dengan indeks keseragaman adalah komposisi tiap individu pada suatu spesies yang terdapat dalam suatu komunitasNilai indeks keseragaman fitoplankton pada Perairan Pantai Marina yaitu berkisar 0,84-0,88. Nilai indeks keseragaman berkisar antara 0-1 (Odum, 1993). Berdasarkan hasil nilai indeks yang diperoleh (mendekati angka 1), diindikasikan bahwa tingkat keseragaman genus pada masing-masing stasiun itu tinggi (seragam), yang artinya persebaran komposisi genus dalam suatu populasi tidak jauh berbeda atau seragam. Nilai indeks keseragaman yang tinggi menunjukkan bahwa komunitas plankton dalam kondisi yang baik (stabil).

Indeks dominansi digunakan untuk mengetahui sejauh mana suatu kelompok biota mendominansi kelompok lain. Dominansi yang cukup besar akan mengarah pada komunitas yang labil maupun tertekan. Hasil analisis indeks dominansi fitoplankton selama penelitian berada pada 
kisaran rata rata antara 0,12 - 0,14. Berdasarkan nilai itu dapat dijelaskan bahwa kelimpahan setiap genus fitoplankton selama penelitian dalam kondisi merata dan tidak ada yang mendominasi (Basmi, 2000). Hal ini sesuai yang dijelaskan oleh Odum (1993) bahwa nilai indeks dominansi (D) mendekati 0 berarti hampir tidak ada individu yang mendominasi.

Hasil dari penelitian ini, berdasarkan nilai indeks saprobik menunjukkan bahwa Perairan Pantai Marina, termasuk dalam tingkat saprobitas a - Mesosaprobik yang megindikasikan pencemaran sedang hingga berat. Nilai indeks saprobik di Perairan Pantai Marina berkisar antara $(-1,19)-(-0,89)$ dengan nilai terendah pada Pengulangan I dan tertinggi pada Pengulangan III. Nilai indeks saprobik tersebut termasuk dalam a - Mesosaprobik. Menurut Basmi (2000) suatu perairan dengan nilai SI -2 sampai 0,5 tergolong dalam kelompok $\alpha$ - Mesosaprobik. Farichi et al., (2013) mengemukakan tingkat saprobik di perairan yang menunjukkan tingkat pencemaran sedang sampai berat tersebut disebabkan oleh bahan pencemar organik dan anorganik. Adanya perbedaan nilai saprobitas pada setiap stasiun dipengaruhi oleh sifat fisik dan kimia perairan yang akan berpengaruh terhadap organisme saprobik baik langsung maupun tidak langsung (Anggoro, 2013). Kategori a - Mesosaprobik menunjukkan kualitas perairan di Pantai Marina tercemar sedang hingga berat. Menurut Bellingger et al, (2010), kategori $\alpha$ - Mesosaprobik, kesuburan perairannya sulit dimanfaatkan untuk kultivan tertentu dan tidak cocok untuk lokasi budidaya kultivan tertentu. Hal ini dibuktikan dari fitoplankton yang ditemukan, dimana terdapat genera yang toleran terhadap pencemaran bahan organik yang tinggi. Genera tersebut yaitu Nitzschia, Navicula, Synedra, Melosira, Fragilaria, Diatoma, dan Asterionella (Ansa et al., 2011). Kecepatan arus akan berperan dalam proses migrasi dan penyebaran plankton sebagai organisme yang pasif sehingga pergerakannya sangat ditentukan oleh arus (Hawkes, 1978).

\section{KESIMPULAN}

Kelimpahan fitoplankton di seluruh Pengulangan berkisar antara 17945,36-20394,24 $\mathrm{sel} / \mathrm{L}$ dengan kategori rendah. Indeks keanekaragaman $\left(\mathrm{H}^{\prime}\right)$ berkisar antara 2,37-2,44 termasuk dalam kategori sedang. Indeks keseragaman fitoplankton berkisar antara 0,84-0,88 dengan kategori tinggi. Indeks dominansi (C) fitoplankton termasuk dalam kategori tidak ada jenis yang mendominasi dengan nilai indeks yang berkisar antara $0,12-0,14$, serta indeks saprobik di Perairan Pantai Marina memiliki hubungan / status tercemar sedang hingga berat serta analisis hubungan kelimpahan fitoplankton dengan kualitas perairan menunjukkan bahwa parameter lingkungan perairan yang berpengaruh terhadap dinamika fitoplankton adalah suhu, kecerahan, salinitas, nitrat, dan fosfat.

\section{UCAPAN TERIMAKASIH}

Artikel ini adalah bagian dari skripsi dengan judul "Status Kualitas Perairan di tinjau dari Distribusi Fitoplankton serta Indeks Saprobik di Pantai Marina Semarang Jawa Tengah", untuk memperoleh gelar sarjana Strata Satu pada Departemen IImu Kelautan Fakultas Perikanan dan Ilmu Kelautan Universitas Diponegoro

\section{DAFTAR PUSTAKA}

APHA (American Public Health Association). 1989. Standard methods for the examination of water and waste water. American Public Health Association (APHA). American Water Works Association (AWWA) and Water Pollution Control Federation (WPCF). 17th ed. Washington. 1193 hal.

Anggoro, S., Soedarsono, P. \& Suprobo, H.D. 2013. Penilaian Pencemaran Perairan di Polder 
Tawang Semarang Ditinjau Dari Aspek Saprobitas. Management of Aquatic, 2(3):109-118.

Adiwilaga, E.M., Harris, E., \& Pratiwi, N.T. 2012. Hubungan antara kelimpahan fitoplankton dengan parameter fisik-kimiawi perairan di Teluk Jakarta. Jurnal Akuatika, 3(2):169-179

Ansa, E.D.O., Lubberding, H.J., Ampofo, J.A., \& Gijzen, H.J. 2011. The role of algae in the removal of Escherichia coli in a tropical eutrophic lake. Ecological Engineering, 37(2):317324. DOI : 10.1016/j.ecoleng.2010.11.023

Basmi. 2000. Planktonologi : Organisme Penyusun Plankton, Klasifikasi dan Terminologi, Hubungan antara Fitoplankton dan Zooplankton, Siklus Produksi umumnya di Perairan. Fakultas Perikanan IPB, Bogor. 23-25 hlm.

Bellinger, E.G. \& Sigee, D.C. 2010. Freshwater algae: Identification and use as bioindicators. Oxford, UK: John Wiley \& Sons, Ltd.

Chapman, L.J., Balirwa, J., Bugenyi, F.W.B., Chapman, C. \& Crisman, T.L. 2001. Wetland of East Africa: Biodiversity, Exploitation, and Policy Perspective. Biodiversity in wetlands: assesment, function and conservation. Volume 2 Edited by B. Gopal, W.J. Junk \& J.A. Davis. Backhuys Publishers, Leiden, The Netherlands, 101-131 p.

Dresscher \& Van der Mark. 1976. A simplified method for the biological assesment of the quality of fresh and slightly brackish water. Journal Hydrobiologia, 48(3):199-201.

Effendi, H. 2003. Telaah Kualitas Air Bagi Pengelolaan Sumberdaya dan Lingkungan Perairan. Kanisus. Yogyakarta. HIm 57-58.

Fachrul, M.F. 2007. Metode Sampling Bioekologi. Bumi Aksara. Jakarta.

Farichi, A., Suharto, B., \& Susanawati, L.D. 2013. Analisa Kualitas Perairan Sungai Klinter Nganjuk Berdasarkan Indeks Diversitas Dan Saprobik Plankton. Jurnal Keteknikan Pertanian Tropis dan Biosistem, 1(2).36-42

Hutabarat, S., \& Evans, S.M. 1984 . Pengantar Oseanografi. Penerbit Universitas Indonesia.

Hawkes, H.A. 1978. Invertebrate as Indicator of River Water Quality. University of Newcastle. Upon Tyae, Newcastle.

Insafitri, I. 2010. Keanekaragaman, Keseragaman, Dan Dominansi Bivalvia Di Area Buangan Lumpur Lapindo Muara Sungai Porong. Jurnal Kelautan: Indonesian Journal of Marine Science and Technology, 3(1):54-59.

Munthe, Y.V., \& Aryawati, R. 2012. Struktur komunitas dan sebaran fitoplankton di perairan sungsang Sumatera Selatan. Maspari Journal: Marine Science Research, 4(1):122-130. DOI : 10.36706/maspari.v4i1.1437

Nontji, A. 2007. Laut Nusantara. Cetakan Kedua. Djambatan, Jakarta.

Nuriasih, D. M. \& Anggoro, S. 2018. Saprobic analysis to Marina coastal, Semarang city. IOP Conference Series: Earth and Environmental Science. 116(1).

Nawawi, H. 2012. Metode Penelitian Bidang Sosial. Yogyakarta: Gajah Mada University Press.

Nybakken, J.W. 1992. Biologi Laut Suatu Pendekatan Ekologis. PT. Gramedia, Jakarta.

Nurcahyani, E.A., Hutabarat, S. \& Sulardiono, B., 2016. Distribusi Dan Kelimpahan Fitoplankton Yang Berpotensi Menyebabkan Habs (Harmful Algal Blooms) Di Muarasungai Banjir Kanal Timur, Semarang. Journal of Management of Aquatic Resources, 5(4):275-284.

Odum, E.P. 1993. Dasar - Dasar Ekologi. Edisi Ketiga. Universitas Gadjah Mada Press, Yogyakarta. HIm 697.

Suhartono, E. 2010. Identifikasi kualitas perairan pantai akibat limbah domestik pada monsun timur dengan metode indeks pencemaran (studi kasus di Jakarta, Semarang, dan Jepara). Wahana Teknik Sipil, 14(1):51-62.

Simanjuntak, M. 2009. Hubungan Faktor Lingkungan Kimia, Fisika terhadap Distribusi Plankton di Perairan Belitung Timur, Bangka Belitung. Jurnal Perikanan, 11(1): 31-45.

Sari, A.N., Hutabarat, S. and Soedarsono, P., 2014. Struktur Komunitas Plankton pada Padang Lamun di Pantai Pulau Panjang, Jepara. Journal of Management of Aquatic Resources, 3(2):82-91.

Siagian, M. 2012. Jenis Dan Keanekaragaman Fitoplankton Di Waduk PLTA Koto Panjang, Kampar, Riau. Bumi Lestari Journal of Environment, 12(1):99-105. 
Yulianto, D., Muskananfola, M.R. \& Purnomo, P.W. 2017. Tingkat Produktivitas Primer Dan Kelimpahan Fitoplankton Berdasarkan Waktu Yang Berbeda Di Perairan Pulau Panjang, Jepara. Journal of Management of Aquatic Resources, 3(4):195-200.

Welch, P.S. 1980. Limnology. Second edition. McGraw Hill International Book Company. New York. 